\title{
Direct and Residual Effect of Nutrient Management and Rice Establishment Methods on Productivity, Profitability, Nutrient Uptake and Resource Use Efficiency in Rice (Oryza sativa L.)- Groundnut (Arachis hypogaea L.) Cropping System
}

\author{
T.K. Samant ${ }^{1}$, L.M. Garnayak², R.K. Paikaray ${ }^{2}$, K.N. Mishra ${ }^{3}$, R.K. Panda ${ }^{4}$, S.K. Swain ${ }^{5}$
}

10.18805/LR-4762

\begin{abstract}
Background: Rice and rice based cropping systems are of prime importance in global food production but continuous rice mono cropping and excessive dependence on chemical fertilisers degrade the soil quality, which can be partly solved by changing into ricelegume system.

Methods: The field experiment was conducted during kharif and rabi of 2019-2020 and 2020-2021 at Odisha University of Agriculture and Technology, Bhubaneswar to evaluate direct and residual effect of nutrient management and rice establishment methods on productivity, profitability, nutrient uptake and resource use efficiency in rice-groundnut system.

Result: Transplanted rice increased the yield attributes of rice in both the years resulting in $6.0-8.1 \%$ higher grain yield than direct seeding. Integrated nutrient management (INM) significantly improved the growth and yield of rice as compared to sole organic and inorganic. Carryover effect of direct seeding increased growth and yield of succeeding groundnut. Residual effect of organic in preceding rice increased pod yield of groundnut. INM to groundnut increased yield parameters of the crop resulting in 19.7-20.2 and $38.9-40.0 \%$ higher pod yields than $100 \%$ and $75 \%$ soil test based fertiliser, respectively in both the years. Direct seeding of rice with INM practice in both the crops performed superior in rice-groundnut cropping system.
\end{abstract}

Key words: Cropping system, DSR, Economics, Groundnut, INM, Nutrient uptake, Resource use efficiency, TPR.

\section{INTRODUCTION}

Rice (Oryza sativa L.) and rice based cropping systems are of prime importance in global food production. India occupies the world's largest area under rice (44.5 Mha) and is the second highest producer (172.5 Mt paddy) contributing $22 \%$ of global rice production. Groundnut (Arachis hypogaea L.) is considered as important legume oilseed crop contributing nearly $18 \%$ of the total oilseed production in India (201819). Continuous rice mono cropping and excessive dependence on chemical fertilisers degrade the soil quality, which can be partly solved by changing into rice-legume cropping system. It is pertinent to suggest suitable rice based cropping system and nutrient management practices in order to get more yield and income with maintaining the soil fertility and inclusion of oilseeds and legumes in the cropping system has closer relationship between cropping system productivity, energy and environment (Deep et al., 2018).

Use of high analysis fertilisers debars the crop of availing the micronutrients and balanced fertilization. Organic manures and biofertilizers have carry-over effect on the succeeding crops in rice based cropping systems. Efficient nutrient management through integration of all possible sources of nutrients can fulfill the phasic requirements of crops and increase crop productivity.

Groundnut being a legume-oilseed crop, its nutrients requirement is quite high. Low productivity in groundnut is mainly due to use of imbalanced plant nutrients and
${ }^{1}$ Krishi Vigyan Kendra, Odisha University of Agriculture and Technology, Angul-759 132, Odisha, India.

2Department of Agronomy; Odisha University of Agriculture and Technology, Bhubaneswar-751 003, Odisha, India.

${ }^{3}$ Department of Soil sciences and Agril. Chemistry; Odisha University of Agriculture and Technology, Bhubaneswar-751 003, Odisha, India.

${ }^{4}$ Department of Plant Physiology; Odisha University of Agriculture and Technology, Bhubaneswar-751 003, Odisha, India.

${ }^{5}$ Directorate of Research, Odisha University of Agriculture and Technology, Bhubaneswar-751 003, Odisha, India.

Corresponding Author: T.K. Samant, Krishi Vigyan Kendra, Odisha University of Agriculture and Technology, Angul-759 132, Odisha, India. Email: tksamant_2003@yahoo.co.in

How to cite this article: Samant, T.K., Garnayak, L.M., Paikaray, R.K., Mishra, K.N., Panda, R.K. and Swain, S.K. (2021). Direct and Residual Effect of Nutrient Management and Rice Establishment Methods on Productivity, Profitability, Nutrient Uptake and Resource Use Efficiency in Rice (Oryza sativa L.)-Groundnut (Arachis hypogaea L.) Cropping System. Legume Research. DOI: $10.18805 /$ LR-4762.

Submitted: 04-08-2021 Accepted: 09-11-2021 Online: 18-12-2021 application of manures and fertilizers affects the availability of soil nutrients and soil physical properties of groundnut (Salma et al., 2018). Method of stand establishment influences the performance of rice crop and has great impact 
Direct and Residual Effect of Nutrient Management and Rice Establishment Methods on Productivity, Profitability, Nutrient...

on field preparation and establishment of succeeding rabi crop. Puddling in TPR results deterioration of soil physical properties which make land preparation becomes difficult and requires more energy to achieve proper soil tilth leading to yield reduction in succeeding rabi crop. Keeping these above points in view, the present investigation was undertaken to find out direct and residual effect of different nutrient management and rice establishment methods on productivity, profitability, nutrient uptake and resource use efficiency in rice-groundnut cropping system.

\section{MATERIALS AND METHODS}

The field experiment was conducted during kharif and rabi season of 2019-2020 and 2020-2021 at Agronomy Main Research Farm, Odisha University of Agriculture and Technology, Bhubaneswar under East and South Eastern Coastal Plain Agro-Climatic Zone of Odisha. The soil of the experimental site was acidic in reaction ( $\mathrm{pH}-5.28)$, loamy sand texture with medium organic carbon $(0.57 \%)$, phosphorus $(15.4 \mathrm{~kg} / \mathrm{ha})$ and potassium $(189.4 \mathrm{~kg} / \mathrm{ha})$ and low in nitrogen $(187.5 \mathrm{~kg} / \mathrm{ha})$ content. Six treatment combinations comprising of two establishment methods [direct seeded rice (DSR) and transplanted puddled rice (TPR)] and three nutrient management practices [inorganic- $100 \%$ soil test based fertilizers (STBF), organic-green manuring $+1 / 3^{\text {rd }}$ Soil Test Based Nitrogen (vermicompost) $+1 / 3^{\text {rd }}$ STBN (neem oil cake) and integrated nutrient management (INM)-green manuring $+50 \%$ STBN $+100 \% \mathrm{P}_{2} \mathrm{O}_{5}+100 \% \mathrm{~K}_{2} \mathrm{O}$ ] to rice during kharif were allotted to the main-plots. Three nutrient management practices viz., 75\% STBF (inorganic), 100\% STBF (inorganic) and INM $[75 \%$ STBN (inorganic) $+25 \%$ STBN (FYM) + lime $0.2 \mathrm{LR}+$ biofertilisers (Rhizobium and PSB) $+100 \% \mathrm{P}_{2} \mathrm{O}_{5}+$ $100 \% \mathrm{~K}_{2} \mathrm{O}$ ] to groundnut during rabi were allotted to the subplots in a split-plot design replicated three times at the same site during both the years in rice-groundnut cropping system. Rice (cv. Maudamani-CR DHAN 307) and groundnut variety (cv. Devi-ICGV 91114) were grown with recommended package of practices. Vermicompost@2.0 t/ha and neem oil cake @0.87 t/ha were applied in rice immediately after layout of the experiment as per treatments. Inorganic nutrient management practices of 100\% of STBF @100:40:40 and $25: 40: 40 \mathrm{~kg} \mathrm{~N}: \mathrm{P}_{2} \mathrm{O}_{5}: \mathrm{K}_{2} \mathrm{O} /$ hawere applied in rice and groundnut respectively.

All the growth, yield attributes and yield of both crops were recorded as per standard procedures. The formulae used for calculating different efficiencies were:

\begin{tabular}{|c|c|}
\hline Efficiency & Formula \\
\hline \multirow{3}{*}{ Employment generation efficiency (\%) } & Total mandays employed for the system \\
\hline & 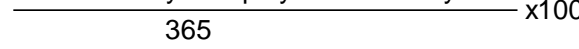 \\
\hline & System yield (kg REY/ha) \\
\hline Partial factor productivity (kg REY/kg NPK added) & Total addition of NPK in the system ( $\mathrm{kg} / \mathrm{ha})$ \\
\hline & Energy output (Mj / ha) \\
\hline Energy use efficiency & $\overline{\text { Energy input (Mj / ha) }}$ \\
\hline \multirow{2}{*}{ Heat use efficiency $\left(\mathrm{g} / \mathrm{m}^{2} /{ }^{\circ} \mathrm{C}\right.$ day $)$} & Total dry matter $(\mathrm{g} / \mathrm{m} 2)$ \\
\hline & Cumulative growing degree day $\left({ }^{\circ} \mathrm{C}\right.$ day $)$ \\
\hline
\end{tabular}

Available soil nutrient contents were determined following the standard procedures (Jackson, 1973). The data collected from the experiment on various observations of both crops were subjected to statistical analysis as prescribed by Gomez and Gomez (1984).

\section{RESULTS AND DISCUSSION}

\section{Growth and yield of rice}

Direct seeded rice (DSR) recorded (Table 1) significantly higher plant height and tillers $/ \mathrm{m}^{2}$ over transplanted rice (TPR) in both the years, which might be due to transplanting shock in TPR and higher plant density in DSR. Rice crop under TPR produced more dry matter and comparatively higher leaf area index (LAI), which might be responsible for higher yield attributes in TPR resulting in yield improvement of 8.0 and $6.0 \%$ over DSR during 2019 and 2020, respectively. This could be due to better microclimatic condition and improvement in soil physico-chemical properties for better water uptake as well as availability and utilization of nutrients in TPR (Bastola, 2020). Integrated nutrient management (INM) in rice resulted 12.4 and $17.7 \%$ higher grain yield over inorganic and organic practice during 2019-20 and 14.0 and $12.8 \%$ during $2020-21$. Better performance of rice crop with INM had led to increase in plant growth resulting in higher grain yield. Saini et al. (2019) opined that beneficial effects of green manuring in crop production should not be evaluated in isolation; however, in integration with chemical fertilizers.

\section{Growth and yield of groundnut}

Residual effect of DSR favourably influenced the growth and yield attributes in succeeding groundnut crop as compared to that grown after TPR resulting in 25.6 and $26.2 \%$ higher pod yield during 2019-20 and 2020-21, respectively (Table 2). and formation of hard pan at shallow depth through puddling in TPR which was detrimental to the succeeding non-rice crop (Bandyopadhyay et al., 2019).

Significantly higher plant height and per plant nodules, dry matter accumulation, pod weight were recorded under the residual effect of organic nutrient management to preceding rice crop in the respective years which resulted in the highest pod yield of 2367 and $2597 \mathrm{~kg} / \mathrm{h}$ a during 2019 20 and 2020-21, respectively. This was on a par with that grown after INM practice in rice, but was on an average, $17.4 \%$ higher than that grown after inorganic practice in rice This might be due to deterioration of soil physical condition 
owing to availability of continuous and balanced supply of nutrients for a prolonged period due to residual effect of organic to preceding rice (Prasad et al., 2002). INM to groundnut increased the growth and yield parameters resulting in 19.7 and $38.9 \%$ higher pod yield during 2019 20 and 20.2 and $40.0 \%$ during $2020-21$ over 100 and $75 \%$ STBF, respectively. This might be owing to increased solubility and availability of $\mathrm{N}$ in the rhizosphere due to biofertilisers, improvement of soil $\mathrm{pH}$ due to lime, physicochemical properties due to FYM and instant availability of nutrients from inorganic fertilisers (Singh et al., 2013).

\section{System yield in rice-groundnut system}

Direct seeding of rice resulted in the system yield of 12.2 and $13.1 \mathrm{t} \mathrm{REY/ha,} \mathrm{in} \mathrm{2019-20} \mathrm{and} \mathrm{2020-21,} \mathrm{respectively,}$ which was 8.0 and $10.1 \%$ higher than grown after TPR (Table 3). Rice yield under TPR was $7 \%$ higher than DSR, but groundnut produced about $26 \%$ higher pod yield when was grown after DSR than TPR. Higher yield as well as higher sale price of groundnut (three times of rice) resulted in higher REY of the system under DSR. INM in rice resulted in, on an average, $12.3 \%$ higher system yield than the inorganic practice, but was at par with the organic treatment in one of the two years, because of higher yield of rice under INM (Table 1) and similar yield of groundnut under residual effect of organic and INM practice in preceding rice crop (Table 2) for the reasons stated earlier. Similarly, INM practice in groundnut improved system yield by 12.1 and $21.8 \%$ over 100 and $75 \%$ STBF, respectively, because of corresponding increase in groundnut yield by 20 and 39\% (Table 2) in conformity with Prasad et al. (2002).

\section{Nutrient uptake in rice-groundnut system}

On an average, DSR resulted in higher uptake of $\mathrm{N}$ by the system $(252.2 \mathrm{~kg} / \mathrm{ha})$, which was $15.6 \mathrm{~kg}$ more than TPR but was at par with the latter with respect to uptake of $P$ and $\mathrm{K}$ (Table 3). INM in rice exhibited higher uptake of $\mathrm{N}, \mathrm{P}$ and $\mathrm{K}$ by the system, followed by organic and inorganic. Similarly, INM practice in groundnut resulted in higher uptake of N, P and $\mathrm{K}$ than 100 and $75 \%$ STBF. The uptake of nutrients followed the trend of system yield in conformity with the findings of Samant (2015).

\section{Resource use efficiency in rice-groundnut system}

The resource use efficiency indices such as land use efficiency (LUE), employment generation efficiency (EMGE), partial factor productivity (PFP), energy use efficiency (EUE) and heat use efficiency (HUE) of the rice-groundnut system were affected by nutrient management and rice establishment methods (Table 3).

TPR registered higher LUE, EMGE and EUE than DSR in both the years. On the other hand, PFP was higher in DSR (53.9 and $58.0 \mathrm{~kg} \mathrm{REY/kg} \mathrm{NPK} \mathrm{added)} \mathrm{than} \mathrm{TPR,}$ whereas both the establishment methods did not influence the HUE values. This might be ascribed to the variations in duration, man-days requirement, input use and yield of component crops. INM to rice resulted in the highest EMGE $82.3 \%$ in both the year and HUE of 1.20 and $1.43 \mathrm{~g} / \mathrm{m}^{2} /{ }^{\circ} \mathrm{C}$ 


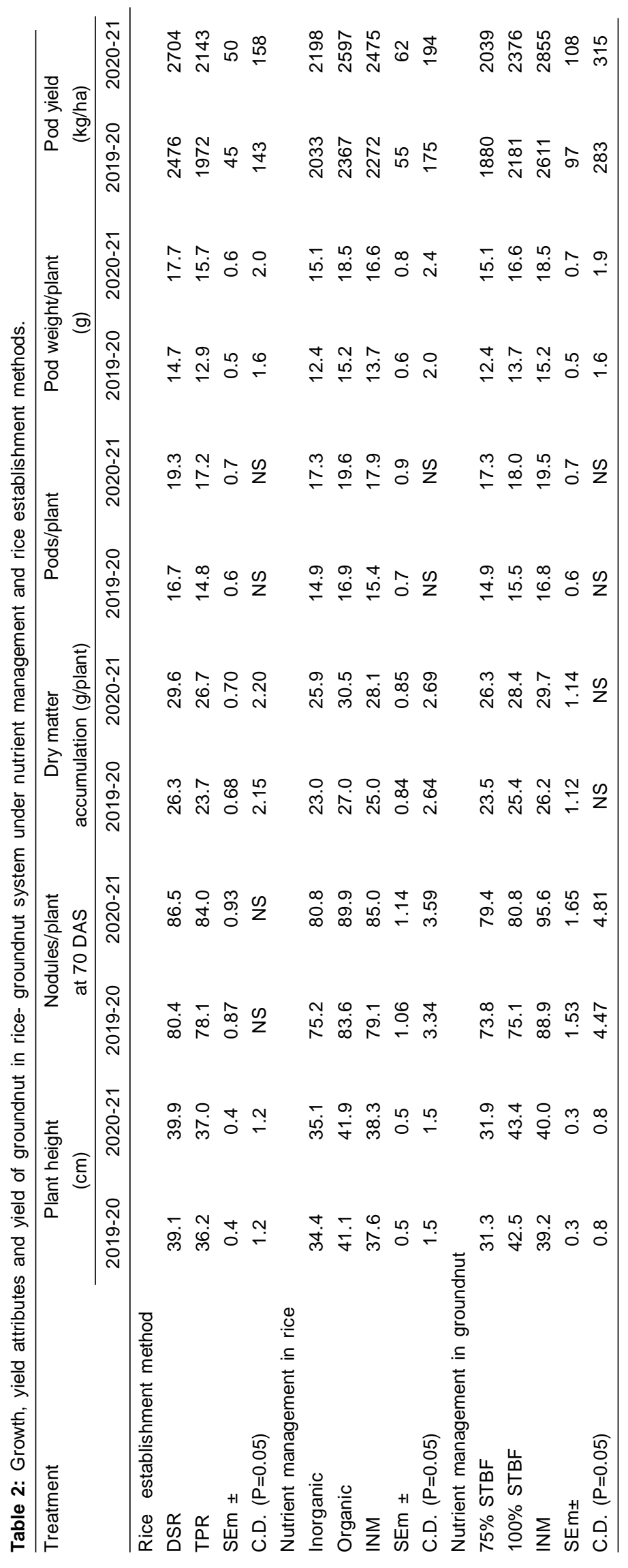




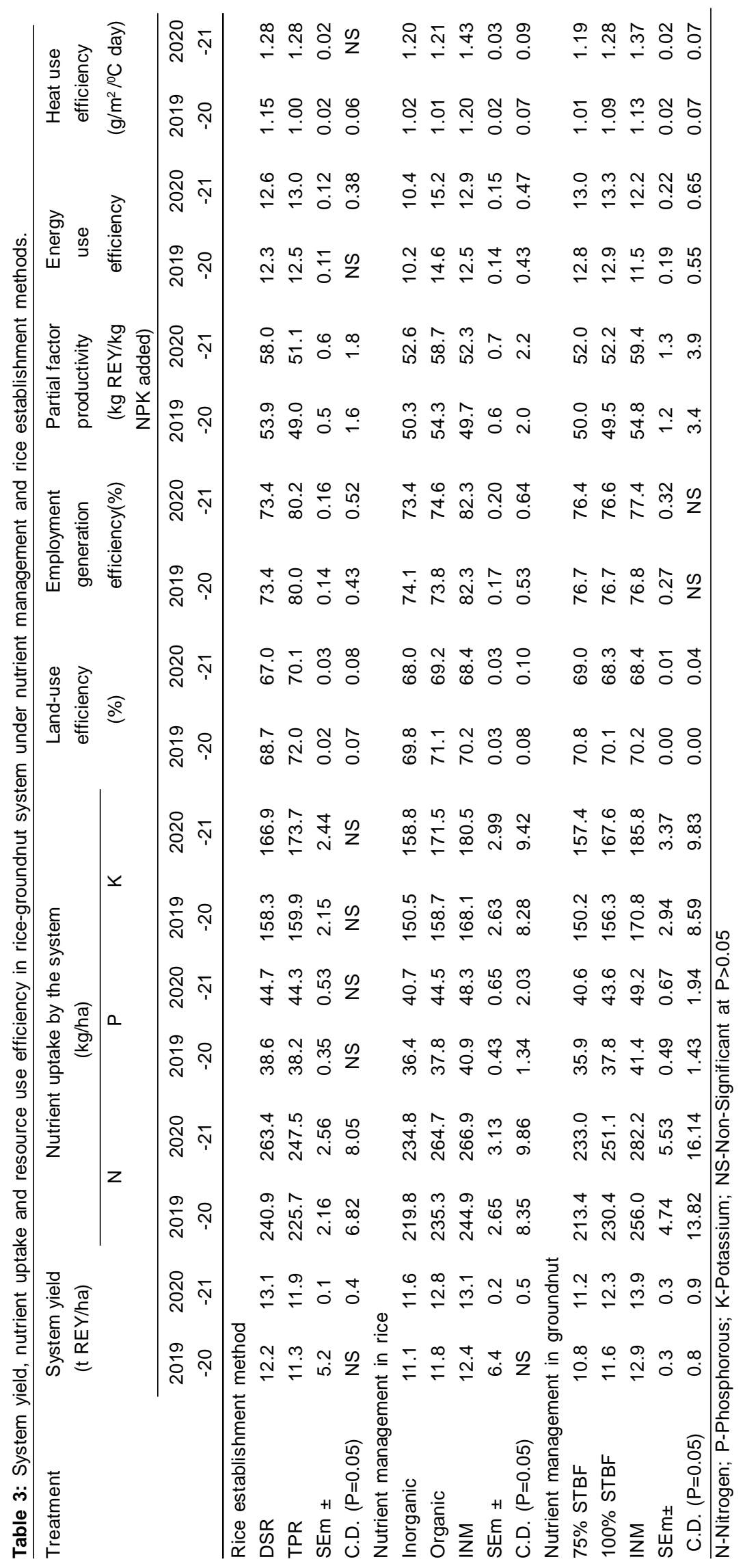




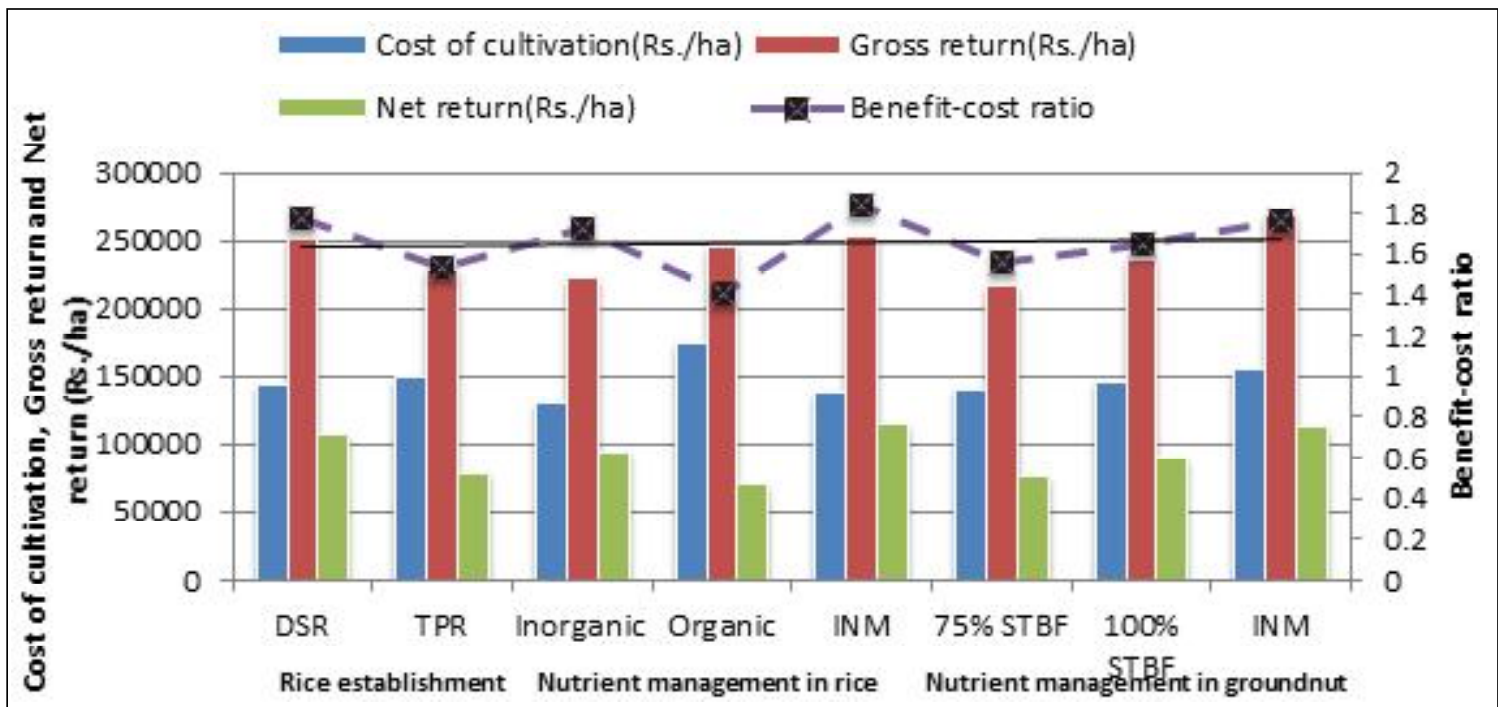

Fig 1: Economics of rice-groundnut system during 2019-20 under nutrient management and rice establishment methods.

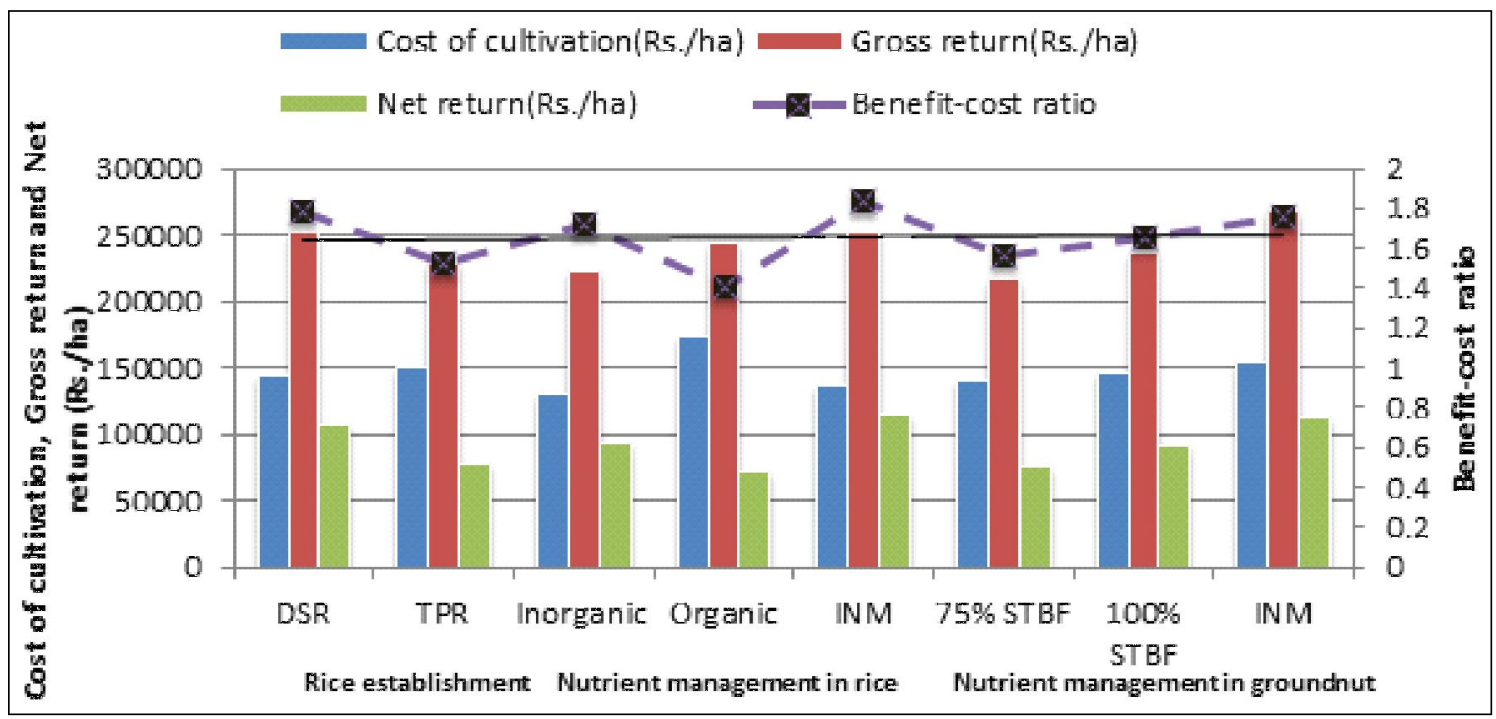

Fig 2: Economics of rice-groundnut system during 2020-21 under nutrient management and rice establishment methods.

day during 2019-20 and 2020-21, respectively. Application of organic sources to rice resulted in higher LUE, PFP and EUE in both the years followed by INM and inorganic in conformity with the findings of Shilpha et al. (2018). INM in groundnut crop in the system resulted in higher average values of EMGE, PFP and HUE of the system than 100 and $75 \%$ STBF. However, EUE was higher in $100 \%$ STBF as compared to INM and $75 \%$ STBF (Patra et al., 2018).

\section{Economics of rice-groundnut system}

Transplanting in rice resulted in higher cost of cultivation of the system in both the years due to higher cost towards man days, but DSR fetched the maximum gross return owing to higher system yield (Fig 1 and Fig 2). The net return value under DSR, on an average, was Rs.27121/ha more than TPR. DSR also improved the B:C to 1.67 and 1.78 as compared to TPR during 2019-20 and 2020-21, respectively, due to relatively less cost of cultivation in conformity with Bohra and Kumar (2015). But INM to rice resulted in the higher average gross returns, net returns and $B: C$ over organic practice and inorganic nutrition might be due to its higher yield. INM to groundnut incurred in higher cost of cultivation of the system and also fetched higher average system gross returns (Rs.257523/ha), net returns (Rs.103434/ha) and B:C (1.69) increasing the corresponding values by Rs. 45857/ha, Rs. 32143/ha and 0.16 unit over $75 \%$ STBF and Rs. 27656/ha, Rs. 18960/ha and 0.09 unit over $100 \%$ STBF. This was due to higher system yield under INM, which might have negated the relatively higher cost of organic sources of nutrients in line with the findings of Samant (2015). 
Direct and Residual Effect of Nutrient Management and Rice Establishment Methods on Productivity, Profitability, Nutrient...

\section{CONCLUSION}

There is carry over effect of nutrient management and rice establishment methods in rice on succeeding groundnut crop. Integrated nutrient management practice in conjunction with dhaincha green manuring $+50 \%$ STBN $+100 \% \mathrm{P}_{2} \mathrm{O}_{5}$ $+100 \% \mathrm{~K}_{2} \mathrm{O}$ under direct seeded rice followed by integrated use of $75 \%$ STBN (inorganic) $+25 \%$ STBN (FYM) + 0.2 LR + biofertilisers (Rhizobium and PSB ) to succeeding groundnut crop is the recommended nutrient management practice for higher productivity, profitability, nutrient uptake and resource use efficiency of rice-groundnut cropping system.

\section{ACKNOWLEDGEMENT}

The first author is grateful to The Director, ICAR-Agricultural Technology Application Research Institute, Kolkata for giving the opportunity to pursue his Ph.D degree.

\section{REFERENCES}

Bandyopadhyay, K.K., Sarangi, A., Kumar, R.D. and Singh, D.K. (2019). Effect of Puddling and direct sowing of rice on soil physical health and water productivity of rice wheat cropping system under different irrigation regimes. Journal of Indian Society of Soil Sciences. 67(2):160-173.

Bastola, A. (2020). A review on effect of establishment methods on growth, yield and yield attributes of rice and on succeeding crops after rice. International Journal for Research in Applied Sciences and Biotechnology. 7(6): 134-139.

Bohra, J.S. and Kumar, R. (2015). Effect of crop establishment methods on productivity, profitability and energetics of rice (Oryza sativa)-wheat (Triticum aestivum) system. Indian Journal of Agricultural Sciences. 85(2): 217-223.

Deep, M., Kumar, R.M. and Saha, S. (2018). Rice-based cropping systems for enhancing productivity of food grains in India: decadal experience of AICRP. Indian Farming. 68(01): 27-30.
Gomez, K.A. and Gomez, A.A. (1984). Statistical procedures for agricultural research. A Willey Inter Science Publication, New York, pp.76-83.

Jackson, M.L. (1973). Soil Chemical Analysis. Prentice Hall of India Private Limited, New Delhi.

Patra, A.K., Mohapatra, B.K., Swain, S.K, Garnayak, L.M., Mishra, K.N., Mohanty, T.R. and Paikaray, R.K. (2018). On-farm evaluation of rice (Oryza sativa)-based cropping systems for increasing system productivity, profitability, resourceuse efficiency and energy productivity in mid-central table land zone of Odisha. Indian Journal of Agronomy. 63(3): 264-270.

Prasad, P.V.V., Satyanarayana, V., Murthy, V.R.K. and Boote, K.J. (2002). Maximising yields in rice-groundnut cropping sequence through integrated nutrient management. Field Crops Research. 75(1): 9-21.

Saini, P.K., Yadav, R.K. and Yadav, G.C. (2019). Green manures in agriculture: A review. Bhartiya Krishi Anusandhan Patrika. 34(1): 1-10.

Salma, D., Venkaiah, K. and Naidu, M.V.K. (2018). Impact on soil properties and yield of rainfed groundnut mono cropping system (Arachis hypogaea L.) under long term application of manure and fertilizers. International Journal of Current Microbiology. 7(12): 1346-1360.

Samant, T.K. (2015). System productivity, profitability, sustainability and soil health as influenced by rice based cropping systems under mid-central table land zone of Odisha. International Journal of Agriculture Sciences. 7(11): 746-749.

Shilpha, S.M., Soumya, T.M., Mamathashree, C.M. and Girijesh, G.K. (2018). Energetics in various cropping systems. International Journal of Pure and Applied Bioscience. 6(4): 303-323.

Singh, G.P., Singh, P.L. and Panwar, A.S. (2013). Seed yield quality and nutrient uptake of groundnut (Arachis hypogaea) as affected by integrated nutrient management in mid hill attitude of Meghalaya India. Legume Research. 36(2): 147-152. 